\title{
Théophile Gautier, Euvres complètes, Voyages, t. V. Voyage en Russie
}

\section{Lise Sabourin}

\section{(2) OpenEdition}

10 Journals

\section{Édition électronique}

URL : http://journals.openedition.org/studifrancesi/8001

DOI : 10.4000/studifrancesi.8001

ISSN : 2421-5856

Éditeur

Rosenberg \& Sellier

\section{Édition imprimée}

Date de publication : 1 juillet 2009

Pagination : 424-425

ISSN : 0039-2944

\section{Référence électronique}

Lise Sabourin, "Théophile Gautier, E Euvres complètes, Voyages, $t$. V. Voyage en Russie », Studi Francesi

[En ligne], 158 (LIII | II) | 2009, mis en ligne le 30 novembre 2015, consulté le 08 janvier 2021. URL

http://journals.openedition.org/studifrancesi/8001; DOI : https://doi.org/10.4000/studifrancesi.8001

Ce document a été généré automatiquement le 8 janvier 2021.

\section{(c) (i) (9)}

Studi Francesi è distribuita con Licenza Creative Commons Attribuzione - Non commerciale - Non opere derivate 4.0 Internazionale. 


\title{
Théophile Gautier, Euvres complètes, Voyages, t. V. Voyage en Russie
}

\author{
Lise Sabourin
}

\section{RÉFÉRENCE}

THÉOPHILE GAUTIER, CEuvres complètes, Voyages, t. V. Voyage en Russie, établissement du texte, notice et variantes par Serge ZENKINE, notes par Natalia MAZOUR et Serge ZENKINE, Paris, Honoré Champion, «Textes de littérature moderne et contemporaine», 2007, pp. 606.

1 Les deux voyages effectués en Russie par Gautier, de septembre 1858 à mars 1859, puis d'août à octobre 1861, auraient dû aboutir à assurer la partie littéraire de l'immense entreprise des Trésors d'art de la Russie ancienne et moderne conçue après la guerre de Crimée pour renouer les relations culturelles entre la France et l'Empire. Mais malgré le soutien impérial, le projet n'aboutit qu'à quelques livraisons. C'est donc un écrit personnel qui est sorti de ce double périple, de Berlin, Hambourg et Lübeck par bateau à Saint-Pétersbourg et Moscou, puis en train directement à Saint-Pétersbourg, Moscou, avant de descendre la Néva jusqu'à Nijni-Novgorod. Le Voyage en Russie paru dans «Le Moniteur universel» sous la forme de journal d'impressions - «L'Hiver en Russie» du 11 octobre 1859 au 13 janvier 1860, «L'Été en Russie» en octobre 1861 - s'est complété ensuite pour l'édition chez Charpentier en 1866 de trois textes détachés parus dans d'autres journaux, sur un spectacle à l'Opéra de Saint-Pétersbourg, sur le peintre Zichy et sur Saint-Isaac. Avec le recul du temps, la documentation de Gautier s'enrichit, mais le témoignage personnel s'efface un peu, au profit d'embyrons romanesques, d'autant que le voyageur s'en tient au silence sur les questions politiques, pourtant vives en ce début de réformes d'Alexandre II, vu la nécessité où il est d'obtenir des autorisations pour se déplacer.

2 Suivant le même itinéraire que Custine, il ne traite donc pas de considérations idéologiques, mais se consacre aux paysages de ce pays de plaine que cet apolitisme 
voulu lui rend peut-être un peu plat, le privant ainsi de l'étude des auteurs russes contemporains. On ne peut que regretter l'absence des analyses littéraires si pertinentes habituellement chez ce critique. Malgré la fréquentation de tout un cercle d'artistes à Saint-Pétersbourg, certaines lacunes picturales - ainsi du musée de l'Ermitage - tiennent peut-être au caractère morcelé résultant de l'inaboutissement du projet initial, mais aussi sans doute à la quête d'un exotisme oriental et/ou nordique qui l'incline parfois à quelques visions sceptiques sur les influences reçues par l'art russe. Gautier finalement donne surtout à apprécier la musique - religieuse ou tzigane notamment: si ce livre est «descriptif comme les autres récits de voyage de Gautier, c'est peut-être moins à son oeil qu'à son ouïe musicale que l'auteur a dû ses meilleurs moments vécus au pays blanc du la neige», conclut le préfacier russe Serge Zenkine (p.17). Avec Natalia Mazour, il a enrichi ce volume d'une abondante annotation précisant les réalités observées par l'écrivain ainsi que ses propres références culturelles, textuelles, biographiques - dans lesquelles les index finaux des noms, des personnages et des œuvres permettent de circuler facilement. 